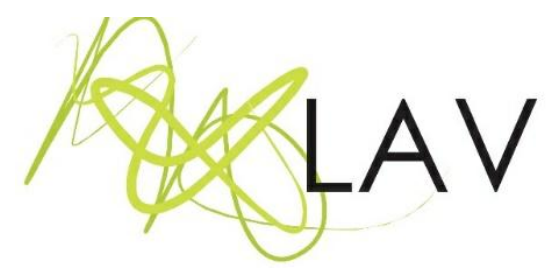

\title{
Arte na formação inicial docente para a pequena infância: uma análise a partir dos cursos de Pedagogia de duas universidades públicas brasileiras
}

Art in Early childhood teacher education: an analysis based on the pedagogy courses of two Brazilian public universities

\author{
Cleriston Izidro dos Anjos \\ Universidade Federal de Alagoas \\ Ana Paula Cordeiroi \\ Universidade Estadual Paulista Júlio de Mesquita Filho \\ Luciana Aparecida de Araújoiii \\ Universidade Estadual Paulista Júlio de Mesquita Filho
}

\section{Resumo}

Este artigo propôs analisar a matriz curricular de dois cursos de Pedagogia de universidades públicas, bem como as ementas das disciplinas de arte com o intuito de verificar o espaço dessa área do conhecimento na formação inicial de educadores/as da infância. A investigação se desenvolveu mediante revisão de literatura, pesquisa documental e narrativa de estudantes referente às suas vivências com arte nos cursos de Pedagogia. Os resultados indicam que os cursos analisados precisam ampliar o espaço dedicado à arte na formação inicial docente para a pequena infância, considerando a necessidade de uma formação que contemple conhecimentos do campo da Educação Infantil aliados à experiência artística e cultural. Conclui-se que há um longo caminho a ser percorrido na elaboração de propostas curriculares comprometidas com a capacidade crítica e criadora do ser humano.

Palavras-chave: Arte, formação docente, pedagogia, currículo, pequena infância.

\begin{abstract}
This article proposes to analyze the curricular matrix of two Pedagogy courses from public universities, as well as the curriculum of the art disciplines, in order to verify the space of this area of knowledge in the initial education of childhood educators. The investigation was developed by means of literature review, documentary research and students narrative regarding their experiences with art in Pedagogy courses. The results indicate that the analyzed courses need to expand the space dedicated to art in initial teacher training for small children, considering the need for training that includes knowledge in the field of Early Childhood Education combined with artistic and cultural experience. It is concluded that there is a long way to go in the elaboration of curricular proposals committed to the critical and creative capacity of the human being.
\end{abstract}

Keywords: Art, teacher training, pedagogy, curriculum, early childhood. 


\section{Introdução}

A formação inicial docente tem sido objeto de estudos e pesquisas preocupados com proposições mais consistentes em relação à docência e sua complexidade. No bojo dessas discussões, residem os cursos de licenciatura em Pedagogia e os/as profissionais nele formados.

O campo de atuação centrado na docência é fruto de disputas históricas. Relembrando o processo que ocorreu no país, na definição de política de formação de professores, no período da regulamentação da atual Lei de Diretrizes e Bases da Educação nacional, a partir da qual muitos embates ocorreram entre pesquisadores, professores e representantes da oficialidade, em torno de diferentes concepções e propostas de formação docente. (GONDIM; FERNANDES, 2011, p. 506).

Segundo Penitente (2013) os cursos de Pedagogia vivem uma "crise de identidade" em função da ambiguidade da legislação sobre as funções que o/a professor/a deve desempenhar, colocando a Pedagogia como área de conhecimento e o pedagogo como agente principal de sua produção; da separação das disciplinas dos currículos dos cursos de Pedagogia em teóricas e práticas, sendo as primeiras voltadas para os conteúdos específicos e/ou fundamentos, e as segundas voltadas para as práticas, concentradas em estágios, metodologias e vivências. Para Gondin e Fernandes (2011, p. 504) a identidade do professor-pedagogo é socialmente construída e requer discussão nos cursos de formação docente, uma vez que essa formação envolve [...] a produção de subjetividades críticas e criativas, o que pode ser compreendido como um dos propósitos do ensino de arte.

A partir dessas considerações iniciais, apresentamos os resultados obtidos com o desenvolvimento de atividades de ensino, pesquisa e extensão desenvolvidas nos Cursos de Pedagogia da Universidade Federal de Alagoas (UFAL) e da Universidade Estadual Paulista "Júlio de Mesquita Filho", Faculdade de Filosofia e Ciências, Campus de Marília.

O presente artigo tem como objetivo analisar a matriz curricular de dois cursos de Pedagogia de universidades públicas, especialmente as ementas das disciplinas de Arte nos respectivos cursos de modo a analisar o espaço da Arte nos currículos de formação inicial para a pequena infância. Esperamos responder aos seguintes questionamentos: que oportunidades de contato com a Arte têm tido os/as estudantes de Pedagogia e que relevância essa disciplina tem assumido na formação inicial? Qual a importância da Arte no processo de formação humana e profissional de professores/as da Educação Básica, especialmente os/as que atuam/atuarão com a pequena infância? 
Partimos do princípio de que, para que tenhamos crianças apreciadoras e criadoras de Arte, se faz necessária uma formação sólida que inclui conhecimentos das áreas da Educação Infantil e da Arte, incluindo experiências de ampliação do repertório artístico e cultural. Daí a importância de ter disciplinas específicas de Arte nas matrizes curriculares dos cursos de formação de professores/as.

Para a discussão sobre a formação docente, tomamos os estudos de Lüdke e André (2005), Gatti e Barreto (2009) e Penitente (2013), bem como documentos oficiais, tais como Leis, Decretos, Pareceres e Resoluções, Brasil (1961, 1968, 1971, 1982, 1988, 1996, 1997, 1999, 2002, 2006a, 2006b). Nos aspectos relacionados à Arte, sustentamos nossas reflexões e análises em Benjamin (1984), Fisher (1971), Martins e Picosque e Guerra (1998), Coli (1981), Canclini (1984), Gondin e Fernandes (2011), Canda e Batista (2009). Os documentos que se constituem como base das considerações sobre arte no currículo de formação das duas instituições envolvidas são os Projetos Pedagógicos de Curso (2006, 2016, 2020), bem como planos de ensino das respectivas disciplinas de Arte.

O caminho metodológico se desenvolveu mediante revisão de literatura, análise documental de Leis, decretos, resoluções, pareceres que trazem o campo normativo dos cursos de formação de professores. Ademais, realizamos entrevistas semiestruturadas e coletamos registros escritos de estudantes referente às suas vivências durante o curso, relacionadas à Arte. Os conteúdos extraídos dos documentos e das entrevistas foram analisados de forma descritiva e interpretativa. Com isso, esperamos que este artigo contribua com as discussões em torno do espaço das artes no currículo de formação de professores, bem como favoreça e desperte o interesse de novas investigações.

\section{Breve contextualização dos Cursos de Pedagogia}

As Diretrizes para os cursos de Licenciatura em Pedagogia (BRASIL, 2006) indicam a responsabilidade de formar docentes para atuar na Educação Infantil nos anos iniciais do Ensino Fundamental e na formação de gestores/as (GATTI; BARRETO, 2009). Gondim e Fernandes (2011, p. 503-504) afirmam que a Arte é considerada como uma disciplina com o mesmo grau de importância das outras áreas de conhecimento nessa formação, tendo em vista o fato de que as Diretrizes para o curso de Pedagogia indicam, no art. 50, item VI a tarefa de "Ensinar Língua Portuguesa, Matemática, Ciências, História, Geografia, Artes, Educação Física, de forma interdisciplinar e adequada às diferentes fases do desenvolvimento humano" (BRASIL, 2006, p. 2). 
Para (GONDIM; FERNANDES, 2011) o lugar que a Arte ocupa no curso de formação inicial docente representa a conquista de concebê-la como conhecimento necessário ao desenvolvimento humano e, portanto, como elemento necessário a ser incorporado ao currículo da Educação Básica. Embora os autores afirmem que a Arte também consta no conjunto das outras áreas de conhecimento da formação inicial docente, Canda e Batista (2009) afirmam que ela - a Arte - ainda é um componente curricular considerado secundário quando comparada com outras áreas de conhecimento.

[...] as aulas na graduação em Pedagogia ainda se restringem a um tipo de conteúdo baseado no intelecto do aluno, em detrimento à ação do corpo, à sensibilidade e ao afeto dos alunos, imperando o silêncio, a leitura e a absorção dos conteúdos selecionados e organizados pelo professor. Por conta disso, a organização do currículo escolar e a prática pedagógica no ensino fundamental tendem a reproduzir os mesmos modelos aprendidos nos campos de formação inicial do educador. Ou seja, sem uma vivência participativa em artes, torna-se difícil para este profissional estimular a prática artística e o potencial criativo dos seus educandos no cotidiano escolar. (CANDA; BATISTA, 2009, p. 109110).

Para as autoras, a Arte não tem recebido o destaque que merece, pois "[...] se contrapõe às práticas pedagógicas tradicionais, baseadas nos paradigmas científicos positivistas da educação[... $]^{\prime \prime}$, concepção que não favorece o seu reconhecimento como processo significativo para o pensamento e ação (CANDA; BATISTA, 2009, p. 110).

\section{Arte e formação inicial docente para a pequena infância}

Antes de nos perguntarmos a respeito do papel da Arte na formação inicial docente nos cursos de Pedagogia, cabe-nos refletir a respeito do papel da Arte na formação humana. Vivemos em um contexto e momento da humanidade em que os aspectos de racionalidade, cognição e objetividade prevalecem sobre outros aspectos da constituição humana. É inegável a importância das ciências e do desenvolvimento cognitivo do ser humano. Mas nos esquecemos, muitas vezes, também, das subjetividades, da sensibilidade, da criação. Não somos apenas cérebro, mas também a soma de nossos desejos, de nossas alegrias, de nossos medos, de tudo o que forma nosso jeito de ser, pensar, sentir e agir.

Benjamin (1984) afirmou que nossos primeiros medos e nossas primeiras alegrias fazem nascer nossos hábitos. Desde o início de nossas vidas, todas as nossas experiências, 
aprendizados e vivências vão nos constituindo. Malaguzzi (1999), em seu conhecido poema "Ao contrário, as cem existem", afirmou que "a criança tem cem linguagens", mas que, no entanto, "roubaram-Ihe noventa e nove". Para ele,

A escola e a cultura Lhe separam a cabeça do corpo

Dizem-lhe:

De pensar sem as mãos

De fazer sem a cabeça

De escutar e de não falar

De compreender sem alegrias

De amar e maravilhar-se só na Páscoa e no Natal.

Dizem-Ihe:

De descobrir o mundo que já existe

E de cem

Roubaram-Ihe noventa e nove.

Dizem-Ihe:

Que o jogo e o trabalho

A realidade e a fantasia

A ciência e a imaginação

$O$ céu e a terra

A razão e o sonho

São coisas que não estão juntas.

Dizem-Ihe:

Que as cem não existem

A criança diz:

Ao contrário,

As cem existem.

(MALAGUZZI, 1999, p. 5).

Há um modo de ser escola que muitas vezes subtrai, ao invés de acrescentar. Almejamos formar uma criança que venha a ser um ser humano integral e participativo, mas muitas linguagens e perspectivas se perdem no meio do caminho. Que escola queremos, que formação pretendemos dar e para quais crianças? A Sociologia da Infância, dentre outras áreas que compõem os Estudos da Infância, preconiza uma criança ativa, criativa, produtora de cultura (CORSARO, 2011) e, nesse sentido, a Arte, elemento da cultura e atividade humana e humanizadora, é fundamental.

Segundo Fischer (1971), a arte conecta o ser humano ao mundo que o cerca e às sociedades humanas de forma dialética. Vamos nos aproximar do mundo e conhecer melhor as coisas por meio do movimento e da mudança. A Arte, e apenas ela, é capaz de unir identificação e não identificação, objetividade e subjetividade, razão e emoção, constância e mudança. 
Nesse artigo, compreendemos a Arte como conhecimento (MARTINS, PICOSQUE; GUERRA, 1998), que se constrói na História. Coli (1981) afirma que não devemos nos preocupar tanto em definir o que é Arte. Para ele,

É possível dizer, então, que arte são certas manifestações da atividade humana diante das quais nosso sentimento é admirativo, isto é: nossa cultura possui uma noção que denomina solidamente algumas de suas atividades e as privilegia. Portanto, podemos ficar tranqüilos: se não conseguimos saber o que a arte é, pelo menos sabemos quais coisas correspondem a essa ideia e como devemos nos comportar diante delas. (COLI, 1981, p. 8).

Canclini (1984, p. 207-9) salienta que

[...] as definições universais e intemporais são idealistas e etnocêntricas, mas podemos formular - mais do que uma definição que encerre o problema- uma caracterização provisória e operacional, um instrumento que permite conhecer a realidade e nele atuar. Se partirmos do que ela foi nos últimos séculos, de sua trajetória em nosso continente e das transformações exigidas por uma estratégia revolucionária, podemos afirmar que a arte abrange todas aquelas atividades ou aqueles aspectos de atividades de uma cultura em que se trabalha o sensível e o imaginário, com o objetivo de alcançar o prazer e desenvolver a identidade simbólica de um povo ou de uma classe social, em função de uma práxis transformadora.

Para Canclini (1984), a Arte abrange aspectos de uma cultura carregados pela sensibilidade e imaginação, une pessoas, aglutina, cria a própria identidade simbólica de um povo. Ocupa, assim, papel central na formação humana e coletiva. Desta forma, os cursos de formação docente não devem prescindir da Arte em suas matrizes curriculares.

Para que tenhamos crianças apreciadoras e criadoras de Arte, é necessário que tenhamos, antes, profissionais que possuam amplo repertório cultural, bem como conhecimento sobre discussões no campo da Arte, para que o trabalho com as crianças possa ser realizado. A formação inicial de professores/as têm papel fundamental na aquisição de conhecimentos e de repertório cultural. A sensibilidade, a capacidade de observar, de criar, de consumir Arte ajudam a formar profissionais mais preparados/as para as necessidades e interesses das crianças.

Os cursos de formação inicial e contínua são muito importantes, porque a maioria dos professores tem conhecimento das novas propostas de ensino da arte, mas sente dificuldade para concretizalas em sala de aula. Não se pode ensinar aquilo que não se conhece. Para tanto, é necessário que o professor entre em contato com o universo da arte, conceitos, procedimentos, valores e vivências, conheça os contextos de produção artística e reflita sobre as obras 
em seus diversos aspectos (histórico, geográfico, estético, político, social, étnico, de gênero). (ARSLAN; IAVELBERG, 2006, p. 06).

A ampliação do repertório cultural de professores/as reflete em suas formas de trabalhar, de mediar, de oferecer atividades, de selecionar conteúdos, de ouvir, de apontar caminhos, de acolher. Por meio do trabalho com as linguagens artísticas, as "noventa e nove linguagens das crianças" podem ser devolvidas e desenvolvidas de forma mais plena e adequada aos propósitos de uma educação humana e sensível.

As expressões "linguagem artística" e "produção do conhecimento artístico", segundo Gondim e Fernandes (2011, p. 508) trazem "[...]uma concepção contemporânea que concebe a arte como produto cultural presente na vida nas diferentes idades e contextos", capaz de estimular e sensibilizar o outro a pensar a respeito dessa sensibilização a partir de contextos históricos que trazem valores sociais e culturais. Para os autores, a educação artística e também cultural deve ser vivenciada não somente em detrimento de atividades de ensino, mas pela perspectiva da formação integral e estética humanas, garantida mediante atividades criadoras e que considerem a Arte como conhecimento. Nesse sentido, defendem que o ensino, nos cursos de Pedagogia, deve trazer a arte como mediadora do processo formativo. Com isso, através de atividades cotidianas, o/a estudante pode compreender a arte e receber formação estética (GONDIM; FERNANDES, 2011).

Optamos pela revisão bibliográfica com o intuito de buscar conhecimentos e informações que se relacionaram ao nosso estudo (LIMA; MIOTO, 2007), além da análise documental, como proposto por Guba e Lincon (1981), a partir de documentos oficiais, disponibilizados, online, no formato de domínio público, como Leis, decretos, resoluções, pareceres que possuem o campo normativo dos cursos de formação de professores, possibilitando-nos compreender como os documentos legais abordam e regulam as ações em torno da reestruturação dos cursos de formação de professores/as e as mudanças nas matrizes curriculares a partir dessas reformulações.

Além disso, buscamos nos valer de fontes tais como o Projeto Político Pedagógico do curso de Pedagogia da FFC/Unesp/Marília e da UFAL, bem como das ementas das disciplinas "Metodologia e Prática do trabalho Pedagógico: arte e movimento" e ArteEducação, disponibilizadas sob domínio público. Mediante trabalho de campo, optamos por trazer para esta análise excertos de transcrições de entrevistas semiestruturadas e registros escritos de estudantes referente às suas vivências relacionadas à disciplina de Arte. 
Recorremos à entrevista semiestruturada por se tratar de um instrumento privilegiado na obtenção de dados e informações, que poderia nos auxiliar em maior profundidade e abrangência, no que diz respeito ao espaço e relevância que o ensino de Artes tem assumido na matriz curricular dos cursos de Pedagogia. Tanto na coleta quanto na divulgação, os dados foram assegurados por princípios éticos. Os conteúdos extraídos dos documentos e das entrevistas que refletem o propósito de nossa investigação foram sistematizados em dois eixos de análise: 1) O espaço da disciplina de Artes na matriz curricular dos cursos de Pedagogia da FFC/Unesp/ Marília e da UFAL; 2) Os benefícios da disciplina de Artes no curso de Pedagogia da FFC/Unesp/Marília e da UFAL, analisados de forma descritiva e interpretativa.

Analisamos as matrizes curriculares de dois cursos de universidades públicas, no sentido de observar o papel que a Arte ocupa neles. Trata-se apenas de um recorte escolhido, o qual não tem nenhuma pretensão em esgotar a compreensão da temática. Desse modo, analisamos os currículos dos cursos de Pedagogia, responsáveis pela formação de professores/as para atuarem na Educação básica. Serviram de suporte para a nossa análise os documentos institucionais, o projeto político-pedagógico dos cursos de Pedagogia da FFC/Unesp-Marília e da UFAL e as ementas das disciplinas que abordam a Arte em tais documentos. Começaremos pela análise da matriz curricular do curso de Pedagogia da FFC- Unesp-Marília e, em seguida, da UFAL.

\section{A matriz Curricular do Curso de Pedagogia da FFC/Unesp/Marília e a disciplina de "Metodologia e prática do trabalho Pedagógico: arte e movimento"}

O curso de Licenciatura em Pedagogia da FFC-Unesp, Campus de Marília, está voltado para a formação de professores, que devem ser formados para a função do magistério na Educação infantil - anos iniciais do Ensino Fundamental, cursos de Ensino Médio, na modalidade Normal, de Educação Profissional na área de serviços, de apoio escolar e áreas que envolvam conhecimentos pedagógicos. Tais princípios foram pensados a partir do artigo $4^{\circ}$ da Diretriz Curricular Nacional (BRASIL, 2006b).

Ademais, pautados na constituição Federal, os objetivos do curso de Pedagogia estabelecem que: "As universidades gozam de autonomia didático científica, administrativa e de gestão financeira e patrimonial, e obedecerão ao princípio da indissociabilidade entre ensino, pesquisa e extensão" (BRASIL, 1988, Art. 207). 
As atividades docentes também compreendem participação na organização e gestão de sistemas e instituições de ensino, englobando: I - planejamento, execução, coordenação, acompanhamento e avaliação de tarefas próprias do setor da Educação; II - planejamento, execução, coordenação, acompanhamento e avaliação de projetos e experiências educativas não escolares; III - produção e difusão do conhecimento científicotecnológico do campo educacional, em contextos escolares e nãoescolares, definiu-se que o curso deverá preservar a boa qualidade da formação no âmbito dos fundamentos, os relevantes conhecimentos presentes nas habilitações e melhor articular os componentes disciplinares em vista da formação de docentes para atuar na Educação Infantil e nos Anos Iniciais do Ensino Fundamental e na Gestão Educacional. Além disso, os docentes deverão atuar a partir de uma perspectiva inclusiva e estar preparados para identificar e receber em suas salas estudantes com necessidades educacionais especiais. Quanto à produção e difusão do conhecimento científico e tecnológico, tal como estabelece o Parecer CNE/CP, no 5/2005, das Diretrizes Curriculares Nacionais para o Curso de Pedagogia: "O curso de Pedagogia oferecerá formação para o exercício integrado e indissociável da docência, da gestão dos processos educativos escolares e não-escolares, da produção e difusão do conhecimento científico e tecnológico do campo educacional" (BRASIL, 2006a, p. 10), serão reorganizadas as disciplinas de iniciação científica, incluindo a oferta permanente aos estudantes do Trabalho de Conclusão de Curso como optativa. (PROJETO PEDAGÓGICO, 2006, p. 10).

Os conhecimentos da habilitação "Magistério para a Educação Infantil" passam a fazer parte da estrutura básica do curso. As disciplinas de Conteúdos, Metodologia e Prática de Ensino passam a ser direcionadas à formação docente para atuar na Educação Infantil e nos anos iniciais do Ensino Fundamental. Conteúdos que dizem respeito a concepções de leitura, escrita, matemática, arte e movimento são abordadas na Educação Infantil e anos iniciais do Ensino Fundamental. Para o segundo semestre do $4^{\circ}$ ano do curso de Pedagogia são oferecidos os aprofundamentos em Educação Infantil, Gestão Escolar e Educação Inclusiva (PROJETO PEDAGÓGICO, 2006).

O curso de Pedagogia da FFC (UNESP-Marília) é constituído por 3360 horas, sendo que 105 horas devem ser cursadas em disciplinas optativas e 300 horas em um dos três aprofundamentos, no intuito de atender o artigo 12 da Resolução CNE/CP no 2/2015, e ao alcance dos objetivos prioritários do curso: formar docentes para atuação na Educação Infantil, nos Anos Iniciais do Ensino Fundamental e na Gestão em Educação, contemplando também a perspectiva inclusiva, a matriz curricular do curso contempla três núcleos de estudos: 
a) Núcleo de estudos de formação geral, destinado aos fundamentos da educação, às teorias, conteúdos, metodologias e práticas do ensino e às teorias e práticas de gestão;

b) Três Núcleos de aprofundamentos e diversificação de estudos dedicados à Educação Infantil, à Educação Especial e à Gestão Educacional. O graduando deverá optar por um destes núcleos, que serão oferecidos para duas turmas: uma no matutino e outra no noturno, e ministrados no último semestre do $4^{\circ}$ ano.

c) Núcleo de estudos integradores (alteração para 'Práticas como Componente Curricular'), constituído por projeto, programa de estudos ou de atividades, a ser elaborado pelos professores e estudantes de cada semestre, em cada uma das turmas, exceto no último semestre do curso. As atividades programadas objetivam articular a integração das disciplinas do semestre em torno de um eixo temático comum. Essas atividades podem, inclusive, ter continuidade no semestre seguinte ou mesmo no ano letivo posterior, caso docentes e estudantes julguem pertinente dar continuidade à proposta. Os estudos integradores possuem caráter teórico-prático, portanto distintos de aulas, e até o ano de 2018 correspondiam a 15 horas da carga horária de cada disciplina de 75 horas, tal como explicitavam os planos de ensino. Com base na Deliberação CEE 154/2017, a partir de 2019, estas atividades recebem outra configuração, sob orientação do Conselho Estadual de Educação; seguindo a Resolução CNE 02/2015, que trata das 'Práticas como Componente Curricular', a Deliberação 154/2017 exige que os cursos de licenciatura promovam a mesma forma de estudos, oferecendo aos alunos do curso, nas disciplinas que preveem carga horária dessa natureza, além das atividades em sala de aula, momentos em que ele possa integrar-se e interagir com o terreno da escola (PROJETO POLÍTICO PEDAGÓGICO, 2020, p.19).

Visando uma articulação integral entre as atividades desenvolvidas, estes três núcleos de estudos articulam-se com os Estágios Supervisionados, sistematizados em três áreas: Estágio Supervisionado de Prática de Ensino na Educação Infantil, Estágio Supervisionado de Prática de Ensino nos Anos Iniciais do Ensino Fundamental e Estágio Supervisionado de Gestão Educacional. Tendo início no primeiro semestre do $3^{\circ}$ ano e podendo serem concluídos até o final do curso (PROJETO PEDAGÓGICO, 2006).

As atividades teórico práticas de aprofundamento (ATPA), em conformidade com a Deliberação CEE no 154/2017 e com a Resolução $n^{\circ} 2$, de 10 de julho de 2015, compreenderão a carga horária correspondente à carga horária anteriormente denominada como AACC (105h), acrescida da carga horária destinada às disciplinas optativas/TCC (105), totalizando 210 horas. A carga horária de $105 \mathrm{~h}$, anteriormente sob a denominação de AACC e, atualmente, compreendida como carga horária de ATPA, refere-se ao envolvimento do aluno com empreendimentos de natureza cultural, científica e acadêmica que sejam contributivos para sua formação plena como pedagogo e serão realizadas pelo estudante, no transcorrer do curso, conforme sua disponibilidade e interesse (PROJETO POLÍTICO PEDAGÓGICO, 2020, p.25). 
O curso de Pedagogia da FFC/Unesp/Marília possui 3360 horas, 105 horas devem ser cursadas nas disciplinas optativas e 300 horas em um dos aprofundamentos anteriormente apresentados. Ademais, os/as estudantes devem realizar 105 horas em atividades Acadêmico-Científico-Culturais que deverão ser atestadas pelo Conselho de Curso. (PROJETO PEDAGÓGICO, 2006). As disciplinas do curso estão sistematizadas na Matriz Curricular do Curso de Pedagogia, conforme segue:

\begin{tabular}{|c|c|c|}
\hline 10 Ano - 750 horas & $\mathbf{C} / \mathbf{H}$ & \\
\hline \multicolumn{3}{|l|}{10 Semestre } \\
\hline 1 & Filosofia da Educação I & 75 \\
\hline 2 & História da Educação I & 75 \\
\hline 3 & Psicologia da Educação & 75 \\
\hline 4 & Sociologia da Educação I & 75 \\
\hline 5 & Metodologia do Trabalho Científico & 75 \\
\hline \multicolumn{3}{|l|}{$2^{\circ}$ Se mestre } \\
\hline 1 & Filosofia da Educação II & 75 \\
\hline 2 & História da Educação II & 75 \\
\hline 3 & Psicologia do Desenvolvimento I & 75 \\
\hline 4 & $\begin{array}{l}\text { Tecnologias Digitais da Informação e } \\
\text { Comunicação }\end{array}$ & 75 \\
\hline 5 & Sociologia da Educação II & 75 \\
\hline \multicolumn{3}{|l|}{$2^{\circ}$ Ano - 750 horas } \\
\hline \multicolumn{3}{|l|}{$1^{\circ}$ Se mestre } \\
\hline 1 & Fundamentos da Educação Inclusiva & 75 \\
\hline 2 & $\begin{array}{l}\text { Fundamentos da Gestão em } \\
\text { Educação }\end{array}$ & 75 \\
\hline 3 & Psicologia do Desenvolvimento II & 75 \\
\hline 4 & Legislação da Educação & 75 \\
\hline 5 & Didática I & 75 \\
\hline \multicolumn{3}{|l|}{$2^{\circ}$ Se mestre } \\
\hline 1 & Didática II & 75 \\
\hline 2 & Fundamentos da Educação Infantil & 75 \\
\hline 3 & $\begin{array}{l}\text { Administração Educacional: Teoria e } \\
\text { Prática }\end{array}$ & 75 \\
\hline 4 & Política e Organização Educacional & 75 \\
\hline 5 & Estatística Aplicada à Educação & 75 \\
\hline \multicolumn{3}{|c|}{$\begin{array}{l}30 \text { Ano }-375 \text { horas }+300+ \\
405 \text { horas de estágio }-1080 \\
\text { horas }\end{array}$} \\
\hline \multicolumn{3}{|c|}{$1^{\circ}$ Se mestre } \\
\hline 1 & Supervisão Educacional & 75 \\
\hline 2 & $\begin{array}{l}\text { Conteúdo, Metodologia e Prática de } \\
\text { Ensino: Alfabetização }\end{array}$ & 75 \\
\hline 3 & $\begin{array}{l}\text { Conteúdo, Metodologia e Prática de } \\
\text { Ensino: História e Geografia }\end{array}$ & 75 \\
\hline 4 & Pesquisa Pedagógica & 75 \\
\hline 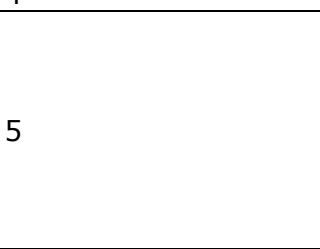 & $\begin{array}{l}\text { Estágio Supervisionado de Prática de } \\
\text { Ensino na Educação Infantil Estágio } \\
\text { Supervisionado de Prática de Ensino } \\
\text { nos Anos Iniciais do Ensino } \\
\text { Fundamental } \\
\text { Estágio Supervisionado de Gestão } \\
\text { Educacional }\end{array}$ & $\begin{array}{l}135 \\
135 \\
135\end{array}$ \\
\hline \multicolumn{3}{|l|}{20 Se mestre } \\
\hline - & $\begin{array}{l}\text { Conteúdo, Metodologia e Prática de } \\
\text { Ensino: Língua Portuguesa e } \\
\text { Literatura Infantil }\end{array}$ & 75 \\
\hline 2 & $\begin{array}{l}\text { Conteúdo, Metodologia e Prática de } \\
\text { Ensino: Ciências }\end{array}$ & 75 \\
\hline
\end{tabular}




\begin{tabular}{|l|l|l|}
\hline 3 & $\begin{array}{l}\text { Conteúdo, Metodologia e Prática de } \\
\text { Ensino: Matemática }\end{array}$ & 75 \\
\hline 4 & Psicologia da Aprendizagem & 75 \\
\hline 5 & Língua Brasileira de Sinais & 45 \\
\hline 6 & Optativa & 30 \\
\hline $\begin{array}{l}\mathbf{4}^{\circ} \text { Ano }-\mathbf{3 7 5}+\mathbf{3 0 0} \text { de } \\
\text { aprofundamento }=\mathbf{6 7 5} \text { horas }\end{array}$ & & \\
\hline
\end{tabular}

\begin{tabular}{|l|l|l|}
\hline \multicolumn{1}{|l|}{$\mathbf{1 0}^{\circ}$ Se mestre } & Optativa & 75 \\
\hline 1 & Jogos e Atividades Lúdicas & 75 \\
\hline 2 & Orientação Psico-Educacional & 75 \\
\hline 3 & $\begin{array}{l}\text { Currículo e as Necessidades } \\
\text { Educacionais Especiais }\end{array}$ & 75 \\
\hline 4 & $\begin{array}{l}\text { Currículo e Projeto Político- } \\
\text { Pedagógico }\end{array}$ & 75 \\
\hline 5 & &
\end{tabular}

APROFUNDAMENTOS (20 Semestre) Educação Infantil (300 horas)
\begin{tabular}{|l|l|l|}
\hline 1 & $\begin{array}{l}\text { Currículo, Metodologia e Prática } \\
\text { do Trabalho Pedagógico com } \\
\text { Crianças de 0 a 3 anos }\end{array}$ & 60 \\
\hline 2 & $\begin{array}{l}\text { Currículo, Metodologia e Prática } \\
\text { do Trabalho Pedagógico com } \\
\text { Crianças de 4 a 5 anos }\end{array}$ & 60 \\
\hline 3 & $\begin{array}{l}\text { Construção do Símbolo na } \\
\text { Infância }\end{array}$ & 30 \\
\hline 4 & $\begin{array}{l}\text { Desenvolvimento Moral na } \\
\text { Criança }\end{array}$ & 30 \\
\hline 5 & Psicogênese do Conhecimento & 60 \\
\hline 6 & $\begin{array}{l}\text { Metodologia e Prática do Trabalho } \\
\text { Pedagógico: Arte e Movimento }\end{array}$ & 60 \\
\hline
\end{tabular}

\section{Educação Especial (300 horas)}

\begin{tabular}{|l|l|l|}
\hline 1 & $\begin{array}{l}\text { Desenvolvimento e } \\
\text { Aprendizagem: Especificidades } \\
\text { das Pessoas com Deficiências }\end{array}$ & 90 \\
\hline 2 & $\begin{array}{l}\text { Comunicação e Sinalização } \\
\text { Diferenciadas na Educação } \\
\text { Especial }\end{array}$ & 90 \\
\hline 3 & $\begin{array}{l}\text { Recursos e Estratégias Didáticas } \\
\text { na Educação Especial }\end{array}$ & 60 \\
\hline 4 & Sexualidade e Deficiência & 30 \\
\hline 5 & $\begin{array}{l}\text { Lingüística Aplicada à Educação } \\
\text { Especial }\end{array}$ & 30 \\
\hline
\end{tabular}

\begin{tabular}{|c|c|c|}
\hline 1 & $\begin{array}{l}\text { Gestão de Sistemas Educativos e } \\
\text { Unidades Escolares }\end{array}$ & 60 \\
\hline 2 & Políticas Públicas em Educação & 60 \\
\hline 3 & Educação Comparada & 60 \\
\hline 4 & $\begin{array}{l}\text { Tópicos Especiais em Gestão } \\
\text { Educacional }\end{array}$ & 60 \\
\hline 5 & $\begin{array}{l}\text { Planejamento e Avaliação na } \\
\text { Perspectiva da Orientação } \\
\text { Educacional }\end{array}$ & 60 \\
\hline
\end{tabular}

Atividades teórico práticas de aprofundamento (ATPA) - (105h correspondentes à carga horária anteriormente denominada como AACC $(\mathbf{1 0 5 h})+\mathbf{1 0 5 h}$ computadas como disciplinas optativas $=$ total de 210h

Total de horas

Quadro síntese/ ch total do curso total Denominação Carga Horária 


\begin{tabular}{|l|l|l|}
\hline $\begin{array}{l}\text { Disciplinas dos Conteúdos } \\
\text { Curriculares e Ensino } \\
\text { Fundamental e Médio }\end{array}$ & 610 & 10 h PCC \\
\hline
\end{tabular}

\begin{tabular}{|l|l|l|}
\hline $\begin{array}{l}\text { Disciplinas de Conteúdos } \\
\text { Específicos e dos Conhecimentos } \\
\text { Pedagógicos }\end{array}$ & 1.735 & $390 \mathrm{~h} \mathrm{PCC}$ \\
\hline $\begin{array}{l}\text { Disciplinas de Formação nas } \\
\text { demais funções }\end{array}$ & 400 & \\
\hline Estágio Supervisionado & 405 & \\
\hline $\begin{array}{l}\text { ATPA (105h carga horária } \\
\text { anteriormente denominada de } \\
\text { AACC + } 105 \text { disciplinas optativas } \\
\text { / TCC) }\end{array}$ & 210 & \\
\hline TOTAL & 3.360 & \\
\hline
\end{tabular}

Quadro 1: Matriz curricular do curso de Pedagogia FFC/ UNESP - MARÍLIA Fonte: Projeto Pedagógico do Curso de Pedagogia da FFC/Unesp/Marília (2020).

Como se pode ver na matriz curricular do curso, há apenas uma disciplina voltada para o trabalho com Arte, em um dos aprofundamentos (de Educação Infantil) do último semestre do $4^{\circ}$ ano de curso. Isso significa que apenas os/as estudantes que optarem pelo aprofundamento em Educação Infantil cursaram a disciplina e terão contato com os conteúdos relacionados à Arte. No último semestre do curso, os/as estudantes de Pedagogia da UNESP-Marília precisam fazer uma escolha por um, entre três aprofundamentos: Educação Infantil, Educação Especial e Gestão em Educação. As três turmas do $4^{\circ}$ ano se dividirão de acordo com as escolhas individuais dos/as estudantes. Sendo assim, é possível afirmar que aproximadamente um terço dos/as estudantes matriculados/as adquiram conhecimentos básicos relacionados à Arte e nem sempre os que escolhem um determinado aprofundamento são os que atuarão na área.

Na primeira década dos anos 2000 houve a reestruturação do curso de Pedagogia e as antigas habilitações, num total de onze, foram extintas, conforme homologação da Resolução do Conselho Nacional de Educação, n. 01 de 15 de maio de 2006 (BRASIL, 2006), que estabeleceu as Diretrizes Curriculares Nacionais para os cursos de licenciatura em Pedagogia. Algumas disciplinas das antigas habilitações ${ }^{1}$ do Curso da UNESP-Marília, foram realocadas no corpo do curso, o que o tornou mais generalista; e os três aprofundamentos foram criados, com novas disciplinas e algumas já existentes. No caso da antiga habilitação em Educação Infantil, disciplinas como "Fundamentos da Educação Infantil" e "Jogos e Atividades Lúdicas" foram realocadas no corpo do curso, para os segundos e quartos anos, respectivamente. O curso de Pedagogia possui três turmas: uma turma no período diurno e duas turmas no período noturno.

\footnotetext{
${ }^{1}$ Cada uma das habilitações do curso de Pedagogia da UNESP de Marília durava entre doze e dezoito meses, sendo que os que optavam em cursar outras habilitações após a conclusão do curso, poderiam ser dispensados/as de disciplinas existentes em comum em algumas dessas habilitações.
} 
A disciplina de "Metodologia e prática do trabalho pedagógico: arte e movimento", que já existia na Habilitação em Educação Infantil, passou a ser oferecida no aprofundamento. Inicialmente, pensou-se em colocá-la no terceiro ano, junto com as disciplinas de "Conteúdos, Metodologia e Prática de Ensino", mas depois de ampla discussão realizada entre os anos de 2005 e 2006 junto à "Comissão de Reestruturação do Curso" foi criada em 2002 uma comissão assessora do Conselho de Curso para estas decisões (PROJETO POLÍTICO PEDAGÓGICO, 2006). Optou-se por deixá-la mesmo no aprofundamento em Educação Infantil, tendo em vista que seus conteúdos se voltavam especificamente a esta etapa educacional.

A disciplina possui setenta e cinco horas de carga horária e a seguinte ementa:

O curso pretende apresentar uma concepção de Arte e Educação para o Movimento que se constitui num valioso recurso pedagógico para o desenvolvimento global do educando e sua formação para a cidadania. Ao conhecer e aprender a lidar com as concepções relacionadas ao movimento e à expressividade e com as diferentes linguagens artísticas, o graduando compreenderá a Arte e a Educação para o Movimento como áreas integradoras das competências verbais e não verbais e de síntese dos processos de cognição, estética, percepção, motricidade, socialização, desenvolvimento emocional e comunicação.

Percebe-se, pela ementa, que a disciplina se divide entre assuntos relacionados ao "movimento", como parte integrante da Educação Física e a Arte e suas áreas. Tem-se, na realidade, uma disciplina para tratar de assuntos de duas áreas de conhecimento. Os objetivos explicitam essa questão. São eles:

Apropriar-se dos processos de construção do conhecimento por meio das linguagens da Arte, articulando a produção artística da humanidade a aspectos conceituais e vivências, relacionados com a educação e seu contexto-sócio-histórico.

- Compreender a Arte como uma área específica de conhecimento, linguagem e formação humana.

- $\quad$ Conhecer os princípios e pressupostos do trabalho de Arte no contexto educacional.

Dominar meios e técnicas para o desenvolvimento das linguagens artísticas na educação infantil, em diferentes contextos. - $\quad$ Conhecer as tendências do trabalho pedagógico de Arte na educação brasileira.

Conhecer os princípios e pressupostos da chamada Educação para o Movimento e sua importância para o desenvolvimento infantil (PLANO DE ENSINO, 2019).

Os objetivos a serem alcançados buscam entrelaçar e aglutinar dentro de uma única disciplina duas áreas de conhecimento que dialogam entre si, mas são distintas e exigem 
na abordagem dos temas esta distinção. No que se segue, apresentamos o conteúdo programático do plano de ensino:

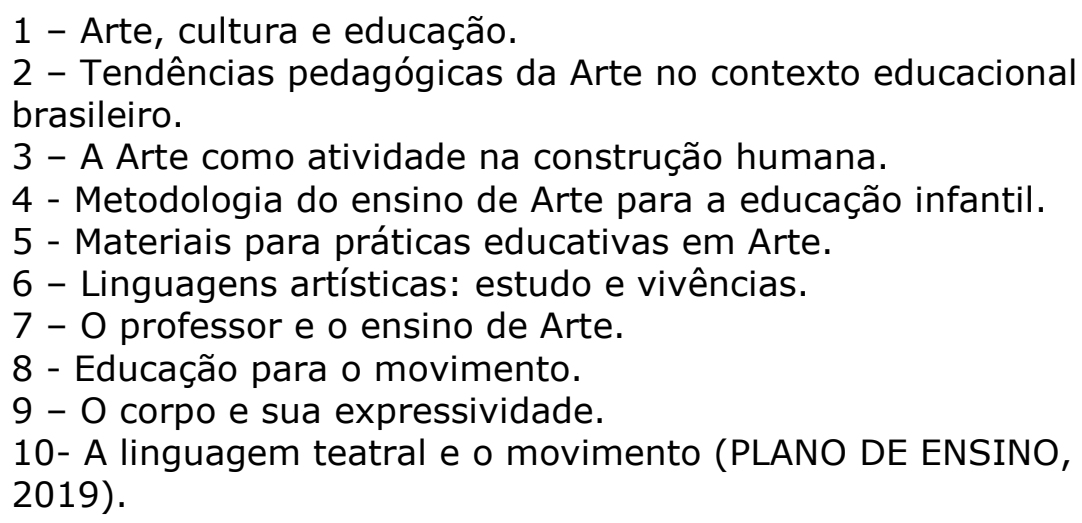

Como é possível visualizar, o conteúdo programático é bastante extenso e busca articular vários assuntos que carecem de maior tempo e espaço para discussões. Cabe ressaltar que a disciplina é teórico-prática, exigindo que sejam trabalhados conteúdos aliados a diversos fazeres das linguagens artísticas e do movimento. Ainda, no que se refere ao movimento, o curso oferece uma disciplina chamada "Jogos e Atividades Lúdicas", mas referente à "Arte", somente tem acesso às discussões os/as que se matriculam no aprofundamento da Educação Infantil.

Voltamos, então, às questões que nos mobilizam essa escrita: que oportunidades de contato com a Arte têm tido os/as estudantes de Pedagogia e que relevância essa disciplina tem assumido na formação inicial? Qual a importância da Arte no processo de formação humana e profissional de professores/as da Educação Básica, especialmente os/as que atuam/atuarão com a pequena infância?

De acordo com os documentos do Curso de Pedagogia da Unesp-Marília, os conteúdos programáticos devem ser trabalhados procurando aliar teoria e prática, com estudos teóricos e oficinas relacionadas às quatro linguagens artísticas: artes visuais, música, dança/movimento e teatro. A participação nas oficinas, os trabalhos e atividades realizadas, resultados das discussões em sala, são formas de avaliação.

Vale ressaltar que a "Metodologia e prática do trabalho pedagógico: arte e movimento" é a única disciplina que aborda especificamente as temáticas relacionadas à Arte. Há outras disciplinas, como "Fundamentos da Educação Infantil", "Currículo, Metodologia e Prática do Trabalho Pedagógico com Crianças de 0 a 3 anos" e "Currículo, Metodologia e Prática do Trabalho Pedagógico com Crianças de 4 a 5 anos", que oferecem algum espaço para que a Arte seja abordada. No entanto, há vários outros conteúdos a 
Arte na formação inicial docente para a pequena infância: uma análise a partir dos cursos de Pedagogia de duas universidades públicas brasileiras

serem trabalhados em tais disciplinas, o que faz com que algumas discussões possam ser prejudicadas.

Destacamos que a ementa analisada associa a ideia de que a arte e suas diferentes linguagens favorecem a aprendizagem, mas também a concebe como campo de conhecimento e apresenta conteúdo específicos, tais como as tendências pedagógicas da Arte no Contexto educacional brasileiro, as metodologias de ensino de arte, a história da arte, entre outros.

[...] as mudanças no ensino de arte se apresentam como um caminho para estimular a consciência cultural do indivíduo, começando pelo reconhecimento da cultura local. Para isso, é necessário que as instituições educacionais deixem de ser meras transmissoras de conteúdos e passem a ser verdadeiras instituições sociais, ajudando os que passam por ela a olharem criticamente para o mundo do qual fazem parte como sujeitos históricos e como cidadãos (HERNANDEZ, 2000). Uma vez que a educação para a compreensão crítica, em última instância, visa a educação para a cidadania, é necessário situar as práticas de mediação entre arte e seus públicos em uma análise que explore as tão frequentemente ignoradas relações complexas entre conhecimento, poder e ideologia, em função das questões de gênero, classe, etnia, sexualidade, idade, entre outras (GONDIM; FERNANDES, 2009, p. 508).

A ementa da disciplina revela a necessidade de se ofertar concepções que discutam o movimento, a expressividade e as diferentes linguagens artísticas como áreas integradoras de comunicações, sejam verbais e não verbais e de processos de cognição, estética, percepção, motricidade, socialização, desenvolvimento emocional e comunicação. Para Canda e Batista (2009, p. 112), a "percepção, sensibilidade, intuição, memória, capacidade de projeção e intencionalidade são algumas das ferramentas mais poderosas que possuímos enquanto espécie humana, todas elas vivenciadas a partir da linguagem e da arte.

\section{A matriz curricular da UFAL}

O projeto do Curso de Pedagogia do Centro de Educação da UFAL (MACEIÓ, 2006²) prevê que o campo de atuação do/a egresso/a está relacionado ao magistério na Educação

\footnotetext{
${ }^{2}$ No momento de escrita desse artigo, o Curso de Pedagogia do Centro de Educação da UFAL está em fase de discussão, atualização e implementação de seu novo projeto pedagógico. No entanto, este não será aqui tomado como objeto de análise, tendo em vista o fato de que não seria possível captar outros elementos de análise para além do documento escrito, tal como a realização de entrevistas com estudantes que passaram pelas possíveis mudanças na proposta de curso. O que se pode afirmar, no entanto, é que alguns debates permanecem antigos
} 
Infantil, nos anos iniciais do Ensino Fundamental, nas matérias do Ensino Médio na modalidade normal e em outros serviços de educação profissional e apoio escolar que tenham à docência como base. Além disso, em conformidade com As Diretrizes Curriculares Nacionais, a organização e a gestão de sistemas e de instituições de ensino e de projetos em contextos escolares e não escolares, bem como a realização de atividades de produção e divulgação do conhecimento científico e tecnológico do campo educacional, também fazem parte dos campos de atuação do egresso do curso.

O Projeto Pedagógico prevê que o perfil almejado pelos membros do curso deve contemplar, dentre outros aspectos:

[...]- capacidade de compreender, cuidar e educar crianças de zero a cinco anos, de forma a contribuir, para o seu desenvolvimento nas dimensões, entre outras, física, psicológica, intelectual e social;

- aptidão para fortalecer o desenvolvimento e as aprendizagens de crianças do Ensino Fundamental, assim como daqueles que não tiverem oportunidade de escolarização na idade própria;

[...] - domínio dos modos de ensinar Língua Portuguesa, Matemática, Ciências, História, Geografia, Artes, Educação Física, de forma interdisciplinar e adequada às diferentes fases do desenvolvimento humano, particularmente de crianças;

[...]. (MACEIÓ, 2006, p. 33-34).

De acordo com o Projeto do Curso de Pedagogia do Centro de Educação da UFAL, o perfil almejado pelos membros do curso deve, portanto, contribuir para a formação de profissionais que compreendam, cuidem e eduquem as crianças, contribuindo para sua formação integral, desde a Educação Infantil. Considera ainda, dentre o conjunto de áreas, o conhecimento relacionado ao trabalho com Arte de modo adequado às fases do desenvolvimento humano como parte integrante do perfil do/a egresso/a.

No que se refere à conteúdos/matriz curricular, considerando a resolução 01/2006 do Conselho Nacional de Educação, a estrutura do curso de Pedagogia do Centro de Educação da UFAL procura dos seguintes núcleos de estudos: i) estudos básicos; ii) aprofundamento e diversificação de estudos e iii) estudos integradores.

O núcleo de estudos básicos, prevê reflexão e ações que considerem:

[...] e) o processo de desenvolvimento de crianças, de jovens e adultos, nas dimensões: cognitiva, afetiva, estética, cultural, lúdica, artística, ética e biossocial;

e atuais ao mesmo tempo, tal como os desafios de formar para diversos campos de atuação em apenas quatro anos de curso. Outros debates tornam a reestruturação ainda mais complexa, como no caso das discussões relacionadas à curricularização da extensão universitária. 
[...] h) a Didática, as teorias e metodologias pedagógicas, os processos de organização do trabalho docente, as teorias de desenvolvimento da aprendizagem; de socialização e de construção do conhecimento, de tecnologias de informação e comunicação e diversas linguagens;

[...] j) o estudo das relações entre educação e trabalho, diversidade cultural, cidadania, sustentabilidade, entre outras questões centrais da sociedade contemporânea;

I) as questões atinentes à ética, à estética e à ludicidade, no mundo de hoje, no contexto do exercício profissional, em âmbitos escolares e não escolares, articulando o saber acadêmico, a pesquisa, a extensão e a prática educativa. (MACEIÓ, 2006, p.34-35).

Dentre os diversos elementos mencionados no Núcleo de Estudos Básicos, destacam-se a presença de termos tais como "estética", "cultural", "lúdica", "artística" (letra E), "diversas linguagens" (letra H), "diversidade cultural" (letra J) e "estética", "ludicidade", "saber acadêmico, pesquisa, extensão e prática educativa" (letra L), sendo que "cultura, estética e ludicidade" aparecem mais de uma vez, o que aponta para significativa preocupação com estas questões na formação do/a pedagogo/a.

O núcleo de aprofundamento e diversificação de estudos prevê que o Projeto Pedagógico deve oportunizar, dentre outras possibilidades, "[...] b) avaliação, criação e uso de textos, materiais didáticos, procedimentos e processos de aprendizagem que contemplem a diversidade cultural da sociedade brasileira; [...]" (MACEIÓ, 2006, p. 35). Aqui, nota-se a presença da "diversidade cultural" como uma preocupação do curso com a formação inicial docente.

O núcleo de estudos integradores, o projeto prevê que o enriquecimento do currículo deve contemplar "[...] c) atividades de comunicação e expressão cultural" (MACEIÓ, 2006, p. 36). No caso da formação docente para a Educação Infantil no Curso de Pedagogia do Centro de Educação da UFAL, esta consta com as seguintes disciplinas específicas: Fundamentos da Educação Infantil e Propostas Pedagógicas (80 horas, 40 período), Saberes e Metodologia da Educação Infantil I (60 horas, $5^{\circ}$ período), Saberes e Metodologia da Educação Infantil II (60 horas, 60 período), Estágio Supervisionado II Educação Infantil ${ }^{3}$ (120 horas, $6^{\circ}$ período), Projetos Integradores VI - Educação Infantil (40 horas, $6^{\circ}$ período). Além destas, existem duas outras disciplinas que embora lotadas no Setor de Estudos em Educação Infantil ${ }^{4}$ Não tratam exclusivamente de conteúdos

\footnotetext{
3 O Estágio Supervisionado na formação inicial para a docência na Educação Infantil no Curso de Pedagogia do Centro de Educação da UFAL tem sido discutido em outras produções, dentre as quais, destacamos: Anjos (2012), Anjos e Miller (2014) e Anjos e Ferreira (2019).

${ }^{4}$ A organização do Centro de Educação da UFAL não se dá por meio de departamentos, mas setores de estudos. Nessa estrutura organizacional, existe um setor específico no qual se encontram e dialogam com os professores da área de Fundamentos e Práticas da Educação Infantil.
} 
relacionados à primeira etapa da Educação Básica (Educação Infantil), mas também contemplam o Ensino Fundamental, a saber: "Jogos, recreação e brincadeiras" (40 horas, $6^{\circ}$ período) e Arte-Educação ( 40 horas, $8^{\circ}$ período). O curso tem carga horária total de 3500 horas.

No que se refere à discussão proposta neste artigo, a partir dessa breve síntese do curso, é possível perceber um dos primeiros desafios para a formação em Arte para a pequena infância no curso de Pedagogia: embora haja um desejo expresso de valorização da Arte, a estrutura do curso conta com apenas uma disciplina específica sobre Arte, com carga horária total de 40 horas para ser distribuída entre os elementos teóricos e vivências e considerando as especificidades da Educação Infantil e dos anos iniciais do Ensino Fundamental, bem como as possíveis formas de Arte.

A seguir, apresentamos um quadro com essas disciplinas e suas ementas, previstas no Projeto de Curso:

\begin{tabular}{|c|c|c|c|}
\hline \multicolumn{4}{|c|}{$\begin{array}{c}\text { Curso de Pedagogia (Presencial) - CEDU/UFAL } \\
\text { Disciplinas de Educação Infantil, Arte e Brincadeiras }\end{array}$} \\
\hline $\begin{array}{c}\text { Saberes / } \\
\text { Componentes } \\
\text { Curriculares }\end{array}$ & $\begin{array}{l}\text { Período / Carga } \\
\text { horária }\end{array}$ & Ementa & Comentários \\
\hline $\begin{array}{l}\text { Fundamentos da } \\
\text { Educação Infantil e } \\
\text { Propostas } \\
\text { Pedagógicas }\end{array}$ & $\begin{array}{l}40 \text { Período / } 80 \\
\text { horas }\end{array}$ & $\begin{array}{lr}\text { Estudo } & \text { dos } \\
\text { fundamentos } & \\
\text { pedagógicos, legais e } & \text { da } \\
\text { normativos } & \text { educação infantil e da } \\
\text { organização } & \text { do } \\
\text { currículo, } & \\
\text { considerando } & \\
\text { propostas } & \\
\text { experiências } & \\
\text { pedagógicas } & \\
\text { reconhecidas } & \text { no } \\
\text { âmbito local, nacional } \\
\text { e internacional. }\end{array}$ & $\begin{array}{l}\text { Foco na história, fundamentos, políticas } \\
\text { e propostas pedagógicas. }\end{array}$ \\
\hline $\begin{array}{lr}\text { Saberes } & \mathrm{e} \\
\text { Metodologia da } & \text { dação Infantil I }\end{array}$ & $\begin{array}{l}50 \text { Período / } 60 \\
\text { horas }\end{array}$ & 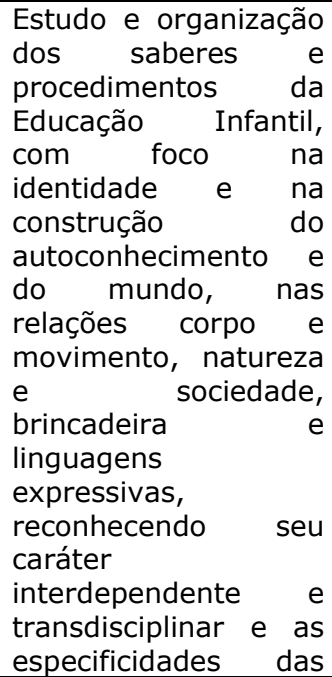 & $\begin{array}{l}\text { A ementa apresenta as linguagens } \\
\text { expressivas como parte dos saberes. }\end{array}$ \\
\hline
\end{tabular}


Arte na formação inicial docente para a pequena infância: uma análise a partir dos cursos de Pedagogia de duas universidades públicas brasileiras

\begin{tabular}{|c|c|c|c|}
\hline & & $\begin{array}{l}\text { diferentes faixas } \\
\text { etárias. }\end{array}$ & \\
\hline $\begin{array}{l}\text { Saberes } \\
\text { Metodologia da } \\
\text { Educação Infantil II }\end{array}$ & $\begin{array}{l}6^{\circ} \text { Período / } 60 \\
\text { horas }\end{array}$ & 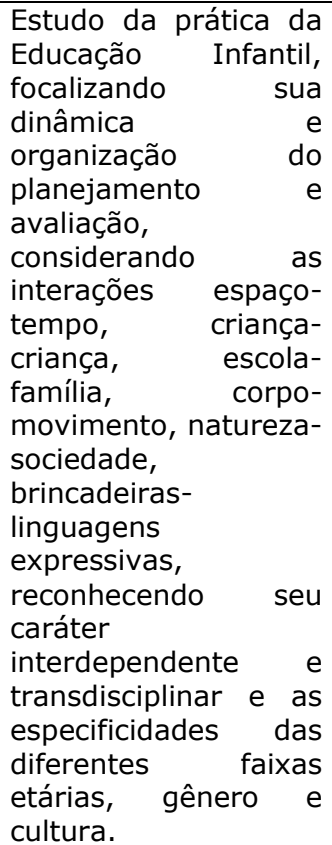 & $\begin{array}{l}\text { A ementa apresenta as linguagens } \\
\text { expressivas como parte dos saberes. } \\
\text { Presença do termo "cultura". }\end{array}$ \\
\hline $\begin{array}{l}\text { Estágio } \\
\text { Supervisionado II - } \\
\text { Educação Infantil }\end{array}$ & $\begin{array}{l}6^{\circ} \text { Período / } 60 \\
\text { horas }\end{array}$ & $\begin{array}{l}\text { Observação e análise } \\
\text { crítica da prática } \\
\text { docente em escola e } \\
\text { ou Centros de } \\
\text { Educação infantil - } \\
\text { campo de estágio. } \\
\text { Elaboração de projeto } \\
\text { / planejamento de } \\
\text { intervenção na escola. } \\
\text { Aplicação execução } \\
\text { do projeto / plano } \\
\text { elaborado para } \\
\text { atuação na escola. }\end{array}$ & $\begin{array}{l}\text { Possibilidade de observação, análise, } \\
\text { planejamento, execução e avaliação de } \\
\text { projetos, envolvendo inclusive o campo } \\
\text { da Arte, embora não necessariamente. }\end{array}$ \\
\hline $\begin{array}{l}\text { Projetos } \\
\text { Integradores VI }\end{array}$ & $\begin{array}{l}6^{\circ} \text { Período / } 40 \\
\text { horas }\end{array}$ & $\begin{array}{l}\text { Elemento integrador } \\
\text { das disciplinas do } \\
\text { semestre letivo, } \\
\text { estruturado a partir de } \\
\text { atividades } \\
\text { interdisciplinares; } \\
\text { como componente do } \\
\text { eixo articulador, terá } \\
\text { como objetivo } \\
\text { principal a reflexão } \\
\text { sobre os elementos da } \\
\text { prática pedagógica no } \\
\text { contexto da divisão } \\
\text { social e técnica do } \\
\text { trabalho escolar, com } \\
\text { base nos saberes } \\
\text { envolvidos naça na } \\
\text { formaca do/a } \\
\text { pedagogo/a, por meio } \\
\text { da observação e } \\
\text { investigação da } \\
\text { realidade educativa, } \\
\text { em especial da prática } \\
\text { pedagógica. }\end{array}$ & $\begin{array}{l}\text { Vincula-se diretamente ao estágio em } \\
\text { Educação Infantil. }\end{array}$ \\
\hline $\begin{array}{l}\text { Jogos, recreação e } \\
\text { brincadeiras }\end{array}$ & $\begin{array}{l}6^{\circ} \text { Período / } 40 \\
\text { horas }\end{array}$ & $\begin{array}{lrr}\text { O jogo e } & \text { as } \\
\text { brincadeiras do ponto } \\
\text { de vista } & \text { da } \\
\text { antropologia } & \text { e da }\end{array}$ & $\begin{array}{l}\text { Considera a indissociabilidade cuidar- } \\
\text { educar, além do fato de que a } \\
\text { brincadeira e as interações se } \\
\text { constituem como eixo do currículo da }\end{array}$ \\
\hline
\end{tabular}




\begin{tabular}{|c|c|c|c|}
\hline & & $\begin{array}{lr}\text { psicologia } & \text { como } \\
\text { conhecimento } & \text { e } \\
\text { procedimento } & \text { de } \\
\text { cuidar, educar } & \text { e } \\
\text { ensinar, } & \\
\begin{array}{l}\text { considerando-se } \\
\text { princípios } \\
\text { socioeducativos } \\
\text { jogar e brincar. }\end{array} & \\
& \text { do } \\
\end{array}$ & $\begin{array}{l}\text { Educação Infantil. Não se trata de uma } \\
\text { disciplina exclusiva da formação docente } \\
\text { para a Educação Infantil. }\end{array}$ \\
\hline Arte-Educação & $\begin{array}{c}8^{\circ} \text { Período / } 40 \\
\text { horas }\end{array}$ & $\begin{array}{l}\text { Conceito } \\
\text { importância das } \\
\text { linguagens artísticas } \\
\text { no fenômeno da } \\
\text { Educação como meio } \\
\text { fundamental para o } \\
\text { desenvolvimento da } \\
\text { criatividade e a } \\
\text { educação estética no } \\
\text { processo } \\
\text { interdisciplinar e e } \\
\text { transdisciplinar do } \\
\text { ensino-aprendizagem } \\
\text { permeado pelas } \\
\text { linguagens artísticas. }\end{array}$ & $\begin{array}{l}\text { Não trata exclusivamente da pequena } \\
\text { infância, embora deva abordá-la } \\
\text { também. Menciona as diversas } \\
\text { linguagens artísticas, a criatividade, a } \\
\text { educação estética e a } \\
\text { interdisciplinaridade/transdiciplinaridade } \\
\text { como elementos constitutivos da } \\
\text { proposta. Carga horária insuficiente, } \\
\text { considerando que precisa abordar as } \\
\text { diversas linguagens artísticas, formação } \\
\text { teórica e vivências e considerar as } \\
\text { especificidades da Educação Infantil e do } \\
\text { Ensino Fundamental. }\end{array}$ \\
\hline
\end{tabular}

Quadro 2: Recorte da Matriz Curricular do Curso de Pedagogia - CEDU/UFAL

Fonte: Quadro elaborado pelo autor e autoras a partir do Projeto Pedagógico do Curso de Pedagogia Presencial - CEDU/UFAL (MACEIÓ, 2006).

\section{Resultados e discussões}

Como resultado de nossas discussões, apresentamos aqui algumas reflexões para pensarmos sobre o espaço que os cursos de formação inicial de professores/as têm dedicado à Arte, tomando como exemplo os dois cursos e suas matrizes, ora aqui apresentados a partir dos dois eixos destacados, conforme segue:

1) O espaço da disciplina de Artes na matriz curricular dos cursos de Pedagogia da FFC/Unesp/ Marília e da UFAL

Em relação à matriz do Curso da FFC-Unesp, percebe-se que a Arte ocupa um espaço bastante reduzido e específico nas discussões educacionais e em disciplinas, cabendo apenas no aprofundamento da Educação Infantil.

Nem todos/as estudantes entrarão em contato com o universo da Arte, tampouco com suas linguagens e conteúdo. Tais discussões provavelmente ficarão restritas a estudantes que optarem pelo aprofundamento em Educação Infantil e que terão, então, acesso à disciplina de "Metodologia e prática do trabalho pedagógico: arte e movimento". Tal disciplina poderia ocupar um espaço junto às disciplinas de "Conteúdos, metodologia e prática de ensino", no terceiro ano, junto a todas as turmas do curso, como ocorre com Língua Portuguesa, Matemática, Ciências, História e Geografia, por exemplo. Porém, 
parece haver o entendimento de que Arte e Movimento cabem apenas nas discussões da Educação Infantil, primeira etapa da Educação Básica.

Na medida em que a criança cresce, outras prioridades surgem e certas disciplinas e conteúdos ocupam todos os espaços, não sobrando tempo para o Movimento e a Arte. Como também já salientamos, em algumas disciplinas específicas do campo da Educação Infantil caberiam discussões sobre Arte e suas quatro linguagens (na verdade, além das quatro, há também as chamadas "artes integradas"), como em "Fundamentos da Educação Infantil", "Currículo, Metodologia e Prática do Trabalho Pedagógico com Crianças de 0 a 3 anos" e "Currículo, Metodologia e Prática do Trabalho Pedagógico com Crianças de 4 a 5 anos", mas do ponto de vista da ementa, objetivos e conteúdo programático, apenas "Metodologia e prática do trabalho pedagógico: arte e movimento" trata especificamente do campo da Arte e garante a obrigatoriedade da discussão.

Cabe destacar, no entanto, ao observarmos o conteúdo programático da disciplina, que as horas precisam ser divididas entre Arte e Movimento. Há diferenças aí entre trabalhar dança/teatro e "movimento", do ponto de vista da Educação Física. Sendo assim, fica ainda mais reduzido o tempo para a discussão sobre as linguagens artísticas na disciplina. Do ponto de vista da diretriz da disciplina, observamos documentos oficiais, tais como a BNCC (BRASIL, 2017), as Diretrizes Curriculares Nacionais para a Educação Infantil (BRASIL, 2009), os PNCNs-Arte (BRASIL, 1997), bem como o Referencial Curricular Nacional para a Educação Infantil, que tratam de três linguagens artísticas: movimento/dança, artes visuais e música (BRASIL, 1998).

As propostas para a disciplina valorizam, além de aulas e referenciais teóricos, também as vivências no campo da Arte, com o oferecimento de oficinas, nas quais atividades são propostas no campo das artes visuais, da música, da dança e do teatro, levando em consideração a criação, apreciação e reflexão na Arte. Cabe ressaltar que a proposta triangular idealizada por Barbosa (1991) está na base dos documentos oficiais citados.

No caso da UFAL, a realidade não é muito diferente com relação ao espaço que a Arte ocupa: há somente uma disciplina específica, com total de 40 horas de atividades de teórico-práticas, cujo docente que a ministra precisa buscar contemplar a Arte na Educação Infantil e no Ensino Fundamental, considerando ainda as artes visuais, a música, a dança e o teatro. 
2) Vozes de participantes da disciplina de Artes no curso de Pedagogia da FFC/Unesp/Marília e da UFAL

Além dos documentos, as vozes dos/as estudantes nos apresentam indícios da disciplina de Arte nos cursos de formação. No caso do Curso de Pedagogia da FFC-Unesp, só podem ser discutidos e mensurados com alunas e alunos que cursaram o aprofundamento em Educação Infantil. Este dado já nos revela a ausência de maiores possibilidades de trabalho e aprendizado no campo da Arte dentro do Curso, tendo em vista que apenas uma disciplina trata do assunto e apenas em um, de três aprofundamentos.

Mesmo com esta ausência ou escassa presença, realizamos entrevista semiestruturada com estudantes do aprofundamento em Educação Infantil (UNESP) e disciplina de Arte-Educação (UFAL), para mensurarmos, mesmo que de forma breve, indícios dessa formação em arte na Pedagogia. No que se segue, apresentam-se seis excertos retirados dessas narrativas de estudantes das duas universidades:

A disciplina me trouxe possibilidades e uma visão sobre a arte como jamais tive. Hoje sou uma educadora mais crítica (penso em como, onde e porque ensinar) e também voltei a me aventurar na arte. (A.O.)

Eu me formei no ano anterior ao início da pandemia e assumi um concurso, como professor de ensino fundamental I, poucos meses após minha formatura. Dado esse contexto, percebo, mais do que nunca, o caráter fundamental da disciplina de "Metodologia e prática do trabalho pedagógico, arte e movimento" para minha formação. Formação essa que extrapola a concepção tecnocrata com a qual muitas vezes nos deparamos no cotidiano do trabalho e que tem, como premissa, a formação de seres em sua integralidade, considerando seus sentimentos e expressões. Hoje, em um sentido afetivo, a lembrança da disciplina, das discussões e das atividades realizadas, é como uma brisa fresca em meio à densidade do momento histórico, repleta de esperança e de força para a construção de um mundo melhor. (G.M.)

A disciplina de Arte-Educação, foi para mim um ampliador de conhecimentos pois, eu tive a possibilidade de estudar um pouco acerca da história da arte, os tipos de artes existentes. Refletindo possibilidades de como inserir uma forma de expressão artística, que desconstrua uma concepção de arte tradicionalista e militante, pautados em desenhos xerocados ou limitando a arte apenas a isso, sem ao menos nenhuma reflexão ou contribuição criativa do sujeito. Um outro ponto que me fez pensar e que também é muito utilizado nas escolas vê a arte como apenas a reprodução de obras de artistas renomados. Acredito ser importante conhecer sobre, porém acredito que para além disso nos momentos de arte permitir o indivíduo a pensar e expressar o seu sentimento através da sua produção, sendo importante disponibilizar diversos tipos de materiais e 
texturas. Um outro ponto que estudamos que chamou muita minha atenção foi as etapas do desenho da criança, que aquilo que muitos chamam de "rabiscos" das crianças pequenas, têm um grande significado e conforme for possibilitado (a) a eles (as), notaremos os avanços que se pode ter ao longo do percurso. Pena que não deu para aprofundar pois como a carga horária é apertada, não deu tempo e também não deu para adentrar em todas as artes visuais existentes focando apenas nas seguintes: desenho, pintura, escultura e artesanato. (RMSF).

Pensar na disciplina Arte-Educação vinculada a grade curricular do curso de Pedagogia na Universidade Federal de Alagoas, antes de cursá-la, imaginei que seria uma disciplina para que pudéssemos entender o que seria Arte e como associar a prática docente ou até mesmo a elaboração das atividades vinculada a arte enquanto elemento cultural de representatividade e manifestação artística. Quando começamos a disciplina percebi que a disciplina poderia contribuir com minha formação para além disso, pois nos suscitou a enxergar a criança enquanto produtora de cultura e a manifestação de seu agir, do falar, do brincar e do produzir os seus objetos e expressões. Logo, a disciplina pode nos subsidiar uma nova visão que foi além das questões nas quais pensávamos que iríamos ver e abordar em Arte e Educação, nos direcionando a um campo subjetivo e pratico sobre os diversos aspectos que a arte pode dispensar aos indivíduos. (MO).

Ao longo do Curso de Pedagogia, me deparei com algumas disciplinas, as quais eu tinha uma prévia visão do que poderia aprender quando cursá-las, uma delas foi a de Arte e Educação, tendo como ponto de vista o que eu estudei sobre Arte durante todo o meu ensino básico, porém fui surpreendida de modo muito positivo, $[\ldots]$, foi um aprendizado muito importante para me constituir como pedagoga, no sentido de ver a Arte e a Educação vinculadas a experiências, que me faziam viajar pelo meu passado enquanto criança e o meu futuro próximo como uma profissional da educação humanizada, afetiva e que precisa no mínimo de ter uma escuta e um olhar, voltados para as manifestações das crianças e suas produções de modo a potencializar e estimular suas descobertas. A Arte aqui apresentada, totalmente diferente da minha vivenciada, nos revelava uma Arte com uma estética que não se preocupa somente com o belo, pois essa característica é muito relativa, ela se preocupa na verdade com o que à obra nos provoca, o quanto ela nos toca e nos leva a dialogar com o artista, quanta sensibilidade e afetividade é necessário para sentir uma Arte, poder viajar pelo mundo, conhecer várias culturas, que nunca seria possível de modo presencial, experimentar essas culturas de modo leve, fazendo com que as crianças sintam-se convidadas a envolverse, explorar e apreender algo novo. Desse modo, ficou muito evidente o que seria Arte e como associá-la a educação, considerando os teóricos estudados, tudo ficaria mais significativo e contribuirá positivamente nas minhas propostas de trabalho pedagógico, hoje já formada e atuando na educação infantil do município de Maceió. Entendo hoje que, meu papel em ampliar a visão do mundo da Arte para minhas crianças, precisa ser algo que elas possam ser marcadas e terem suas memórias afetivas muito 
mais significativas, desde a preparação dos espaços e tempos que proponho acolher as crianças, quanto os materiais disponibilizados para dar possibilidades de as crianças desenvolverem suas produções de forma livre, fazendo suas próprias criações e não apenas imitações, pois entendo que uma produção artística de um profissional renomado, não diminui a criação de uma criança, para validar uma obra, não precisamos comparar ou até mesmo invalidar a outra. Logo entendo a grande importância em ter o privilégio de cursar esta disciplina durante o Curso de Pedagogia, proporcionando aos alunos uma visão necessária para desenvolver a Arte vinculada a Educação. (MSAU).

A disciplina de Arte e Educação se apresentou como um experiência diferente da maior parte das disciplinas pois possibilitou momentos de interação diversificadas como a visita ao museu IPHAN, experiência que eu nunca havia tido, outra experiência que ficou marcante na disciplina foi a visita a uma Escola Municipal de Ensino Fundamental para observar uma aula de Artes para pensar como as atividades eram realizadas, numa perspectiva de pensar sobre a forma tradicional de ensino e a experiência Estética, que Larrosa (2002) e Dewey (1985), apontam que a experiência estética está ligada com a arte e também com as vivencias de cada indivíduo. A disciplina contribui para pensar caminhos para a realização do fazer docente pensando na Arte, Criatividade e imaginação, possibilitando a relação entre o desenvolvimento integral e Educação. É preciso destacar que a disciplina dispõe de uma carga horária pequena para a dimensão e complexidade dos conceitos e discussões que permeiam a disciplina como a reprodução de desenhos e obras por parte dos alunos e a compreensão dos rabisco e desenhos livres das crianças, a ampliação do debate fica comprometida pela carga horária da disciplina ser apenas 40 horas, sendo um dos pontos que deveriam ser repensado. (AFFB).

Os excertos de relatos de estudantes dos Cursos de Pedagogia da UNESP-Marília e do CEDU-UFAL têm em comum o fato de que avaliam a presença de Arte como algo fundamental para a formação docente, especialmente quando essa formação envolve estudos teóricos, oficinas e vivências culturais. Também se destaca nos depoimentos o restrito espaço que Arte ainda ocupa nesses cursos de Pedagogia na medida em que, na UNESP-Marília, estudantes somente tem acesso às discussões relacionadas à Arte se fizerem opção pelo aprofundamento em Educação Infantil e, no CEDU-UFAL, a disciplina possui apenas 40 horas para conta de todo o conteúdo necessário à formação inicial para o trabalho com Arte na educação, em especial na pequena infância.

Na concepção de Canda e Batista (2009, p. 115) o ponto de partida e de chegada de atividades artístico-pedagógicas nos cursos de formação de professores/as não é igual para todos/as. As atividades artísticas devem estar pautadas na "[...]reflexão e nas condições propícias para a expressão e criação de novos códigos de interpretação da 
realidade", influenciando e favorecendo o crescimento pessoal dos/as estudantes, suas ações, no contexto social inserido.

Consideramos que conteúdos, discussões teóricas e oficinas e rodas de conversas com artistas de variados campos das artes (músicos, artistas plásticos e visuais - pintura e fotografia -, atrizes e atores...) podem favorecer uma aproximação e aprendizagens no campo das Artes.

[...] através de atividades artísticas que estimulam o exercício da imaginação, da subjetividade, da memória e elaboração de planos para atividades futuras, estamos dando oportunidades reais cognitivas, sensíveis e inventivas - para o potencial criativo do educando. Ao refletirmos sobre estes aspectos relacionados à criação artística, torna-se imprescindível a ampliação da compreensão sobre o papel da educação, que não deve estar restringida a um contexto puramente racional de compreensão da realidade, conforme vem sendo tratada no âmbito da formação de professores. (CANDA; BATISTA, 2009, p. 113).

Acreditamos que as ações docentes devem dialogar com a experiência artística e cultural, a partir de formas diferenciadas de aprendizagem, propiciando a aquisição crítica e criativa de conhecimentos, de partilha de experiências com o outro, com o mundo em que vivem e convivem.

\section{Considerações finais}

Neste artigo, tivemos como objetivo analisar a matriz curricular dos cursos de Pedagogia destas duas universidades, bem como as ementas das disciplinas de artes dos respectivos cursos para verificar o espaço e relevância da Arte nos currículos de tais cursos. Analisamos os documentos oficiais que regulamentam a educação em nosso país como a Lei de Diretrizes e Bases da Educação Nacional (9.394/96), a Resolução do Conselho Nacional de Educação - CNE/CP, n. 1 de 15 de maio de 2006, que institui as Diretrizes Curriculares para os cursos de Pedagogia.

Buscamos nos valer de fontes primárias como o Projeto Político Pedagógico do curso de Pedagogia da FFC/Unesp/Marília e da UFAL, bem como das ementas das disciplinas de "Metodologia e Prática do trabalho Pedagógico: arte e movimento" e "Arte-Educação".

Assim como Gondin e Fernandes (2019, p. 509) acreditamos que é possível descontruir essa visão de desvalorização da arte como conhecimento, de expressão emocional, e construir de forma crítica e construtiva, uma nova concepção que compreenda 
e aprecie as diferentes formas de expressão e manifestação das diversas culturas como uma forma de ampliar o espaço da Arte na formação inicial docente. Ademais, concordamos com Lazarin (2009, p. 11) ao afirmar que as discussões em torno da arte devem se aproximar das outras áreas, ao invés de afastá-las.

Acreditamos que as ações docentes devem dialogar com a experiência artística e cultural, a partir de formas diferenciadas de aprendizagem, da aquisição crítica e criativa de diferentes conhecimentos, de partilha de experiências com o outro e com o mundo. Conclui-se que há um longo caminho a ser percorrido na elaboração de propostas curriculares, comprometidas com a capacidade crítica e criadora do ser humano. Sabe-se que há disputas e interesses pela garantia de tempo e espaço para as diversas áreas de composição dos currículos de formação docente. Assim como Coutinho (2002, p. 153), acreditamos que "[...] tem-se exigido uma autonomia profissional do professor que pressupõe clareza e responsabilidade nas decisões e escolhas de como e o que ensinar. Estamos, portanto, diante de uma situação reflexiva".

\section{Referências}

ANJOS, C. I.; MILLER, S. Universidade e escola em parceria: uma proposta de projeto para o desenvolvimento do estágio supervisionado destinado à formação do professor de educação infantil. Ensino Em Re-Vista. V.21, N.2, (jul./dez. 2014). Disponível: http://www.seer.ufu.br/index.php/emrevista/article/view/28016. Acesso em: 30 de abr. 2021.

ANJOS, C. I. Estágio na licenciatura em Pedagogia: 3. Arte na Educação Infantil. Rio de Janeiro: Vozes / Maceió: Edufal, 2012.

ANJOS, C. I.; FERREIRA, R. M. S. Formação de docentes para a educação infantil: considerações a partir de um levantamento bibliográfico (2013-2017). revistamultidisciplinar.com, Volume 1 (2), 2019. p. 53-64. Disponível: https://doi.org/10.23882/MJ1920. Acesso em: 30 de abr. 2021.

ARSLAN, L. M.; IAVELBERG, R. Ensino de arte. São Paulo: Thomson Learning, 2006.

BENJAMIN, W. Reflexões: a criança, o brinquedo, a educação. São Paulo: Summus, 1984.

BRASIL. Constituição da República Federativa do Brasil. Congresso Nacional. Brasília, DF, $1988 . \quad$ Disponível em: http://www.planalto.gov.br/ccivil_03/Constituicao/Constituicao.htm. Acesso em: 13 jul. 2018.

BRASIL. Lei Federal n. 5.692, de 11 de agosto de 1971. Fixa Diretrizes e Bases e dá outras providências. Diário oficial da União, Brasília. DF, 12 ago. 1971. Disponível em: http:www010.dataprev.gov.br/sislex/paginas/42/1971/5692.htm. Acesso e: 15 abr.2011. 
BRASIL. Lei Federal no 9.394/1996. Lei de Diretrizes e Bases Nacionais (LDB). Brasília,DF, 1996. Disponível em: http://www.planalto.gov.br/CCivil_03/Leis/L9394.htm. Acesso em: 13 jul. 2018.

BRASIL. Lei n. 7.044, de 18 de Outubro de 1982. Altera dispositivos da Lei no 5.692, de 11 de agosto de 1971, referentes a profissionalização do ensino de $20 \mathrm{grau}$. Disponível em: https://www2.camara.leg.br/legin/fed/lei/1980-1987/lei-7044-18-outubro-1982357120-publicacaooriginal-1-pl.html. Acesso em: 30 abr.2021.

BRASIL. Lei no 4024 de 20 de dezembro de 1961. Fixa as Diretrizes e Bases da Educação Nacional. Disponível em:http://www.planalto.gov.br/ccivil_03/leis//4024.htm. Acesso em: 13 jun.2013.

BRASIL. Lei no 5.540, DE 28 de novembro de 1968. Fixa normas de organização e funcionamento do ensino superior e sua articulação com a escola média, e dá outras providências. Disponível em:http://www.planalto.gov.br/ccivil_03/leis/I5540.htm. Acesso em: 9 jun. 2013.

BRASIL. Parecer CNE/CP 009/2001. Ministério da Educação. Diretrizes para a formação inicial de professores da Educação Básica. Brasília, DF, MEC, 2002. Disponível em:http://www.dominiopublico.gov.br/download/texto/me002179.pdf. Acesso em: 13 jul. 2018.

BRASIL. Parecer do Conselho Nacional de Educação no 5/2005, de 13 de dezembro de 2005, reexaminado pelo parecer no 3/2006, de 21 de fevereiro de 2006. Diretrizes curriculares nacionais para o curso de pedagogia. Diário Oficial [da] República Federativa do Brasil, Brasília, DF, 11 abr. 2006a.

BRASIL. Resolução CNE 001/2002. Institui Diretrizes Curriculares Nacionais para a Formação de Professores da Educação Básica, em nível superior, curso de licenciatura, de graduação plena. Brasília, DF, MEC, 2002. Disponível em: http://portal.mec.gov.br/seesp/arquivos/pdf/res1_2.pdf. Acesso em: 13 jul. 2018.

BRASIL. Resolução do Conselho Nacional de Educação no 1, de 15 de maio de 2006. Institui diretrizes curriculares nacionais para o curso de graduação em pedagogia, licenciatura. Diário Oficial [da] República Federativa do Brasil, Brasília, DF, 16 mai. 2006b - Seção I - p.11.

BRASIL. Secretaria de Educação Fundamental. Ministério da Educação. Referenciais para a Formação de Professores. Brasília, DF, 1999. Disponível em: http://www.dominiopublico.gov.br/download/texto/me002179.pdf. Acesso em: 13 jul. 2018.

Brasil. Secretaria de Educação Fundamental. Parâmetros Curriculares Nacionais Arte. Secretaria da Educação Fundamental - Brasília: MEC, 1997.

CANCLINI, N. G. A socialização da arte: teoria e prática na América Latina. São Paulo: Cultrix, 1984, p. 207.

CANDA, C. N.; BATISTA, C. M. P. Qual o lugar da arte no currículo escolar? Rev. Cient. /FAP, Curitiba, v. 4, n. 2, p. 107-119, jul./dez. 2009.

COLI, J. O que é arte. São Paulo: Brasiliense, 1984.

CORSARO, W. Sociologia da Infância. Porto Alegre: Artmed, 2011. 
COUTINHO, R. G. A formação de professores de arte. In: BARBOSA, Ana Mãe (org.). Inquietações e mudanças no ensino de arte. São Paulo: Cortez, 2002. p. 153-159.

EDWARDS, C. As cem linguagens da criança: a abordagem de Reggio Emília na educação da primeira infância. Trad. Dayse Batista. Porto Alegre: Artmed, 1999.

FISHER, E. A necessidade da Arte. Rio de Janeiro: Zahar, 1971.

GATTI, B. A.; BARRETO, E. S. de Sá. Professores do Brasil: impasses e desafios. Brasília: UNESCO, 2009.

GONDIM J. P.; FERNANDES, A. M. D. Interrogações sobre políticas de formação e ensino de arte nos currículos dos cursos de Pedagogia. Educação e Pesquisa, São Paulo, v. 37, n. 3, p. 497-512, set./dez.2011.

GUBA. E. G.; LINCOLN; Y. S. Effective Evaluation. San Francisco, Ca: Jossey-Bass, 1981.

LAZZARIN, L. F. Problematizações sobre o ensino de Artes Visuais e a Educação Musical. Revista Digital do LAV - Laboratório de Artes Visuais - Revid LAV., v.2, p. 01-17, 2009.

LIMA, T. C. S.; MIOTO, R. C. T. Procedimentos metodológicos na produção do conhecimento científico: a pesquisa bibliográfica. Rev. Katál. Florianópolis v. 10 n. esp. p. 37-45 2007.

LUDKE; ANDRÉ. Pesquisa e formação docente. Cadernos de Pesquisa, v. 35, n. 125, maio/ago. 2005.

MALAGUZZI, L. Ao contrário, as cem existem. In: EDWARDS, Carolyn, GANDINI, Lella, FORMAN, George. As cem linguagens da criança: a abordagem de Reggio Emilia na Educação da Primeira Infância. Porto Alegre: Artmed, 1999.

MARTINS, M. C.; PICOSQUE, G.; GUERRA, M. T. Didática do Ensino da Arte: A Língua do Mundo- poetizar, fruir e conhecer arte. São Paulo: FTD, 1998, p. 41.

PENITENTE, L. A. A Pesquisa Pedagógica nos cursos de licenciatura em Pedagogia: aspectos do trabalho desenvolvido pelos professores. 345f. Relatório final de pesquisa (Pós-Doutorado) - Fundação Carlos Chagas, São Paulo, 2013.

UFAL. Projeto Político-Pedagógico do Curso de Pedagogia. Maceió, 2006. Disponível: https://ufal.br/estudante/graduacao/projetos-pedagogicos/campus-maceio/ppc-

pedagogia-licenciatura.pdf/view. Acesso: 30 de abr. 2021.

UNESP. Plano de Ensino da disciplina de Metodologia e prática do trabalho pedagógico: arte e movimento. Marília.2019.

UNESP. Projeto Político-Pedagógico do Curso de Pedagogia. Marília. 2006. Disponível:

http://www.marilia.unesp.br/Home/Graduacao/Pedagogia/projeto_pedagogico.pdf. Acesso em: 2 ago. 2012.

UNESP. Projeto Político-Pedagógico Do Curso de Pedagogia. Marília. 2020. Disponível em:https://www.marilia.unesp.br/Home/Graduacao/Pedagogia/ppppedagogia-ffc-atualizado.pdf. Acesso em: 25 de abr.2021. 
i Professor Adjunto do Curso de Pedagogia e do Programa de Pós-Graduação em Educação do Centro de Educação da Universidade Federal de Alagoas (CEDU/UFAL/Brasil) e membro do Corpo Docente do Mestrado em Educação Pré-Escolar da Universidade Katyavala Bwila (Angola). Possui graduação em Pedagogia pela Universidade Estadual Paulista "Júlio de Mesquita Filho". Mestrado em Educação pela Faculdade de Educação da Universidade de São Paulo. Doutorado em Educação pelo Centro de Educação da Universidade Federal de Alagoas e Pós-Doutorado em Educação pela Faculdade de Educação da Universidade de São Paulo. Tem experiência na área de Educação, atuando principalmente nos seguintes temas: Educação Infantil, Formação de Professores, Linguagens Expressivas e Culturas Infantis. Coordenador do GEPPECI - Grupo de Estudos e Pesquisas em Pedagogias e Culturas Infantis (CNPq/CEDU/UFAL). Membro Colaborador Doutorado do Centro de Investigação em Estudos da Criança da Universidade do Minho (CIEC/UMinho/Portugal) no grupo "Contextos, quotidianos e bem estar da criança". Integrante da Frente Nordeste Criança (Representação Alagoas) e da Rede Infâncias Negras.

ii Possui graduação em Pedagogia, Mestrado e Doutorado em Educação pela Universidade Estadual Paulista "Júlio de Mesquita Filho". É professora assistente doutora da Universidade Estadual Paulista Júlio de Mesquita Filho, FFC- UNESP - Marília. É docente do Departamento de Didática (atuando no Curso de Pedagogia) e da Pós-Graduação no Mestrado Profissional em Sociologia-Profsocio, na FFC. Tem experiência na área de Educação e atua nos seguintes temas: Educação Infantil, Ensino Fundamental, Sociologia da Infância, Arte e o lúdico na educação de crianças de 0 a 10 anos, Teatro e educação (jogos dramáticos e teatrais na Educação Infantil e nos primeiros cinco anos do Ensino Fundamental, direção teatral, criação teatral coletiva, oficinas de jogos teatrais e processos de criação teatral na terceira idade). É vice-coordenadora do Curso de Pedagogia da FFC-Unesp, Marília. É membro do Grupo de Pesquisa "GP FORME" e do Grupo de Estudos e Pesquisas em Pedagogias e Culturas Infantis (Geppeci-UFAL), atuando principalmente nas linhas de pesquisa "Educação Infantil e Formação de Professores" e "Formação de docentes para a pequena infância". Coordena o Projeto "LUDIBUS", vinculado à PROEX - UNESP e ao Núcleo de Ensino de Marília e o Projeto "Oficinas de Teatro da UNATI (Universidade Aberta à $3^{a}$ Idade) - UNESP de Marília", vinculados à PROEX. Atuou como coordenadora junto ao PIBIDPedagogia - Educação Infantil a partir de 2014 a 2018.

iii Possui graduação em Pedagogia pela Universidade Estadual Paulista "Júlio de Mesquita Filho". Mestrado em Educação pela Universidade Estadual Paulista "Júlio de Mesquita Filho" e Doutorado em Educação pela Universidade Estadual Paulista "Júlio de Mesquita Filho". Fez Pós-doutorado pela Fundação Carlos Chagas. É professora Assistente Doutor da Faculdade de Filosofia e Ciências - Unesp/Marilia, atuando no curso de Pedagogia e no Programa de Pós-Graduação em Educação. Tem experiência na área de Educação, com ênfase na Pesquisa. Atua principalmente nos seguintes temas: Formação de professores, pesquisa pedagógica, pesquisa na formação e prática docente, alfabetização científica e pesquisa com crianças. É Líder do Grupo de Estudos em Pesquisa Pedagógica e Cultura Científica (GEPECC) e pesquisadora do GEPPECI - Grupo de Estudos e Pesquisas em Pedagogias e Culturas Infantis, da Universidade Federal de Alagoas.

Como citar esse artigo:

ANJOS, Cleriston Izidro dos; CORDEIRO, Ana Paula; ARAÚJO, Luciana Aparecida. Arte na formação inicial docente para a pequena infância: uma análise a partir dos cursos de Pedagogia de duas universidades públicas brasileiras. Revista Digital do LAV, Santa Maria: UFSM, v. 14, n. 2, p. 109-138, mai./ago. 2021. 